\title{
ИВАН МИЛЕНКОВИЋ
}

\section{Универзитет у Београду,}

Факултет политичких наука;

Трећи програм Радио Београда, Београд

DOI 10.5937/kultura1549011M

УДК 316.75:141.7

$316.72: 172$

$37.034 / .035: 172$

оригиналан научни рад

\section{ПОЛИТИНКА КУЛТУРА KAO KУЛTУРА ЗАБОРАВA}

Сажетак: Ако је рад на прошлости битан сегмент сваке културе, онда би се политика могла одредити као управљање сећањем. Полазећи од Ничеовог појма ресантимана и Делезовог читањ а Ничеа, овај текст настоји да покаже на који начин и под којим условима политика артикулише циљеве неке културе. Здрава, активна, продуктивна култура, обликује сувереног и самосвесног грађанина, слободног појединца који уме да реагује. Култура ресантимана, томе насупрот, ствара заједнииу поданика који, према ничеанскоделезовској формули, не активирају своју реакиију у име петрификоване прошлости. Окамењеном и инструментализованом сећаюу Ниче супротставља моћ заборављања као својеврсни лек.

Кључне речи: Ниче, Делез, сећање, заборав, култура, политичка култура, парадокс

Сећање је загнојена рана.

Ниче

\section{Култура сећања ${ }^{1}$}

Сећање је садржина културе, а култура је облик сећања. И не само то: култура обликује сећање. Периклов посмртни говор утемељујући је чин једне културе. ${ }^{2}$ Говорити о

1 Текст је настао у оквиру пројекта Родна равноправност и култура грађанског статуса: историјска и теоријска утемељења у Србији (број 47021), који финансира Министарство за просвету, науку и технолошки развој Републике Србије.

2 О жанру посмртног говора у Атини видети бриљантну књигу: Loraux, N. (1993) L'Invention d'Athènes: Histoire de l'oraison funébre dans la cité 
култури сећања утолико је својеврсни плеоназам. Прошлост је најјача временска димензија културе. Нестабилна садашњост и неизвесна будућност стоје на њој као на раменима дива. Истовремено, однос културе према прошлости упућује на виталност те културе, ако је отворена, односно на њену склеротичност, ако је затворена. Као активна, култура увек тумачи прошлост, што не само да прошлост увек чини неизвесном и никад недовршеном димензијом - иако се, разуме ce, оно што се догодило догодило на неповратан начин - већ и културу легитимише као стваралачку, гипку, отворену, интерпретативно самосвесну. С друге стране, ако се схвати као оно што цементира, или армира прошлост, када делује као произвољни тумач прошлости у чијем се тумачењу мешају мит, фантазмагорија и чињенице (као у недавном покушају „константинизације” српске културе), таква култура је склеротична, стереотипизована, нездрава. Таква култура не реагује, него памти. Она не делује, него вежба своје мнемотехничке способности. Здрава култура памти и уме да заборавља. Ритуали у којима преовлађује анахроност - трке коњима у Сиени, рецимо, или „Сињска алка” у Сињу - не упућују на јуначку прошлост, нити су сећање у јаком смислу, већ сведоче о делотворном забораву. Ритуали европских краљевина, рецимо, нису дозивање „боље прошлости”, већ културално обликовање сећања. Ту је реч, наизглед парадоксално, о снази заборава. Али ако једна култура, иста она, рецимо, која 300 година негује „Сињску алку”, пристане на културално петрификовање проблематичног ратног похода из ближе прошлости, та интерпретативна културална интервенција брка прошлост и садашњост утирући крајње небезбедне путеве ка будућности. ${ }^{3}$ У неслободној, збуњеној култури, сећање се преплиће са садашњошћу и, у том преплитању, садашњост поприма чудовишне облике, облике без јасних одређења, по мало као фигуре на Пикасовим сликама које фигуре у себи сједињују више временских димензија и просторних перспектива, па нога без проблема

classique, Paris: Payot.

3 Овде, дабоме, одредница „ближа прошлост” није кључна. Новустановљени празник у Србији, такозвани празник државности, настоји да уведе у колективно сећање дан када је донесен Сретењски Устав, дакле догађај од пре два века. И та културална интервенција грубо брка нивое. О бркању нивоу и смислу понављања видети бриљантну анализу: Делеза, Ж. (2009) Разлика и понављање, превод Миленковић, И., Београд: Федон, стр. 14. „Привидни парадокс празника јесте: поновити 'оно што не може почети изнова', 'што се не може поновити'. Не додавати неки други и трећи пут ономе што се догодило први пут, већ први пут усмерити ка 'ентој' моћи.” Хрватски и српски пример, међутим, упућује да су културалне интервенције изашле из парадокса и унификовале, петрификовале сингуларност. 


\section{ИВАН МИЛЕНКОВИЋ}

извире с места где се, обично, на људском телу налази уво. Чудовиште није, напросто, оно што одступа од нормалног (Адолф Ајхман није чудовиште, како упозорава Хана Арент, зло није чудовишно, оно је банално), већ оно што се опире одређењима (Ајхман је недохватљив не зато што је фасцинантан, као Сократ рецимо, већ зато што је баналан; Ајхман je, захваљујући својој безобличности, био у стању да бесконачно узмиче, да истрајно измиче сваком облику, да се непрестано позива на одсуство одговорности, на то да он није био у стању да донесе одлуку, дакле није био кадар за политички чин; и то је било тачно, њега је нацистичка култура обликовала не као грађанина, већ као послушног поданика).

На овом месту отвара се парадокс својстава. С једне стране грађански идентитет јесте апстрактан и дефинише се управо одсуством унапред датих својстава. Модерни грађанин је форма чија садржина није унапред одређена, те одговорност за садржину сноси сам појединац. С друге стране, иако форма, грађанин не може бити необликован некаквом културом. Грађанин је сада појединац који ступа у недовршен, незатворен, нестабилан однос са културом, стварајући перманентну напетост тамо где је некада, дакле у партикуларној култури, било неупитно уточиште. Однос грађанина и културе није више напросто дат, већ је динамичан, подложан постављању питања. Грађанин би, утолико, био несвојствена својственост, оно што се одређује одсуством културалне садржине (национално одређење, рецимо, пре одлуке самога грађанина). Битна је, дакле општа и нужна форма, док је садржина акцидентална. Ако би се, сада, културална активност одредила као произвођење универзалне форме, једним циничним преокретом - на којем је, уосталом, инсистирао и сам Ајхман - дошли бисмо до човека лишеног свих моралних својстава, одговорног једино за послушно извршавање налога ауторитета. Али Ајхман није грађанин, јер није обликован као активна јединка, већ као послушни пион. Својство грађанина јесте активност. Несвојствена својственост огледа се у слободном обликовању погледа на свет, у суочавању са његовом мноштвеношћу, а не у повлачењу у један разумљиви свет. Образовање таквог грађанина циљ је модерне културе.

Али ко и како одређује циљеве културе, ако је култура већ одређена, у својој најважнијој димензији, односом према прошлости, према сећању којим се хомогенизује заједница? И да ли би снага заборава, у тако одређеној култури, нужно морала да буде негативна величина, или бисмо, заједно с Ничеом, могли да мислимо заборав не као пуку инертну, пасивну, неделатну величину, већ као услов могућности 


\section{ИВАН МИЛЕНКОВИЋ}

здравља једне културе? Да ли се, другим речима, можемо учити забораву?

\section{Циљеви културе}

Синтагма „политичка култура” имплицира барем два негативна одређења: 1. придев „политичка” сугерише да култура може бити и неполитичка; 2. политичка култура супротставља се политичкој некултури. На другом месту тврдили смо да је „политичка култура” својеврсни оксиморон: култура је увек политичка, нема неполитичке културе. ${ }^{4}$ „Аутономна култура" утолико је израз који нуди противречне садржаје. С једне стране то је плеоназам: култура је, по дефиницији, аутономна. Култура која није самозаконодавна није култура. С друге стране то је оксиморон: култура као контекст, као посебност, никада није аутономна јер она је увек захваћена у мрежу односа с другим културама. ${ }^{5}$ Чак и када самој себи даје законе, она није и самодовољна, аутархична, још мање аутохтона. Апсолутност културе је релативна. Култура би, утолико, била аутономија зависности. Култура као безусловни услов. Култура као оксиморон. Најзад, „аутономија културе" сугерише и могућност разликовања културе од других области људскога света, као када говоримо, рецимо, о аутономији политике, или аутономији уметности. Проблем је, међутим, што је људски свет, као вештачки свет, као неприродан свет, увек културалан и не постоји ништа у свету одређеном културом што није културални производ. Свет је култура. То је оно што Хана Арент назива human artifice, човеков вештачки свет. ${ }^{6}$ Не постоји тачка изван културе која би културу одређивала као културу. Култура је самореференцијални систем. Дефиниција културе, свака дефиниција, било која од небројено много дефиниција, увек је већ културално одређена. ${ }^{7}$ Дефиниција културе сама је култура, дефиниција културе јесте култура. Некултура је такође култура.

4 Миленковић, И. Политизација културе и култура политизације, у: Култура, род, грађански статус, ур. Духачек, Д. и Лончаревић, К. (2012), Београд: Центар за студије рода и политике, Универзитет у Београду, Факултет политичких наука.

5 О култури као контексту видети: Миленковић, И. (2015) Парадокси контекста: хетеротопије Мишела Фукоа, Култура бр. 147, Београд: Завод за проучавање културног развитка.

6 Arendt, H. (1958) Conditio humana, Chicago/London: The University of Chicago Press, p. 88, 136.

7 Вероватно најобухватнији покушај да се на једном месту обухвати што већи број дефиниција културе и даље је студија: Kroeber, A. L. and Kluckhohn, C. (1952) Culture: a critical review of concepts and definitions, Papers, 47 (1), Cambridge, Mass: Peabody Museum of Archaeology and Ethnology. Истовремено, тај рад показује у којој мери је дефиниција културе културално одређена, дакле саморефлексивна и самореференцијална. 


\section{ИВАН МИЛЕНКОВИЋ}

Говорити о аутономији културе, дакле, има смисла само ако културу настојимо одвојити од природе, али ту се изнова сусрећемо с негативним одрећењем, већ садржаним у појму културе: култура није природа.

Друга импликација, по којој се политичка култура супротставља политичкој некултури, препознаје се као мањак високе културе код политичких представника одређене заједнице. Колоквијалније, реч је о некултурним људима. Када је владајућа политичка каста обликована елементарном, или примитивном културом, што значи културом која још није доспела до саморефлексије - етничка припадност као највиши израз заједништва, на пример - она не успева културу да разуме као моћ обликовања, као процес образовања, а нарочито самообразовања грађана и заједнице. У примитивним облицима културе природност се не да разлучити од културалних конструката. Штавише, управо је природност највиши циљ културе. У тим случајевима оно политичко схвата се на начин Карла Шмита, као произвођење непријатеља, односно као систем идентификација које претходе самом политичком. Оваква политика, утолико, не носи еманципаторски, већ конзервативни и конзервирајући карактер. ${ }^{8} \mathrm{Hе-}$ достатак политичке културе се, дакле, у овом случају разуме као недостатак културе уопште. Озбиљније је, међутим, што тај и такав недостатак упућује на недостатак смисла за политичко, на политичку неписменост, односно на недостатак смисла политичког, те се речени недостатак, унеколико парадоксално, показује као деполитизовање онога што би имало бити еминентно политичким: јавни се простор приватизује и персонификује, а заједница се окупља око личности, а не политичког представника, или политичке фигуре. Веберов харизматски вођа, односно његова подврста оличена у „слободном демагогу”, у име своје харизме деполитизује јавни простор, те његова харизма ступа на место испражњено од политичког. ${ }^{9}$ Најозбиљнија последица недостатка

8 Упоредити: Шмит, К. (2001) Појам политичког, норма и одлука, превод Баста, Д., Београд: Филип Вишњић. Овако артикулисаном појму политичког најпрородорније се супротставља Жак Рансијер уводећи разлику између политике и полиције, при чему се „полиција” појављује као оно што учвршћује поредак који почива на неупитним идентитетима, док се политика појављује као оно што еманципује од идентитета и нуди „немогуће идентификације” као par excellence политички гест. О „немогућим идентификацијама" видети: Milenković, I. (2014) Nemoguće identifikacije Jacques-a Rancièr-a, Up \& Underground бр. 25/26, Zagreb. Упоредити: Рансијер, Ж (2012) На рубовима политичког, Београд: Федон; Рансијер, Ж. (2014) Несагласност, превод Миленковић, И., Београд: Федон.

9 Вебер, М. (1998) Политика као позив, Духовни рад као позив, превод Јанић, Д., Сремски Карловци/Нови Сад: Издавачка књижарница Зорана 
политичке културе, међутим, огледа се у произвољним и погубним настојањима да се контролишу временске димензије: злоупотреба прошлости, занемаривање садашњости и одсуство будућности константе су деполитизоване културе. Без политичке културе није могуће схватити циљеве одређене политичке заједнице, начине на које она функционише, нити је могуће организовати функционалну политичку заједницу која би имала јасну прошлост, динамичну садашњост и изгледну будућност. Однос према прошлости, динамизовање садашњости и обећање будућности улазе у дефиницију политичке културе.

Политичка култура, тај плеоназам, смисао задобија из циља који је уписан у појам културе. Придев „политичка” упућује на онога ко одређује циљеве културе. Код Канта се, рецимо, циљеви природе поклапају са циљевима културе, те би управо природа била та која одређује циљеве културе, а не некаква политичка структура, још мање политички ауторитет. Грађанско друштво је, утолико, својеврсно средство које би довело до остварења „скривеног плана природе”, до савршеног државног поретка. ${ }^{10}$ Такву поставку о поклапању Кант, међутим, може да одржи по цену парадокса, уводећи хтење и знање у појам природе, а појам недруштвености у појам друштва. ${ }^{11}$ Идеја по којој су култура, уметност, најлепши друштвени поредак, па и слобода, учинак недруштвености, „која саму себе присиљава да се подвргне стези и да тако изнуђеном вештином омогући да се потпуно развију клице природе"12, није друго него имплицитно признање „изнуђена вештина”, дакле култура, политика - да је култура самореференцијални систем. Оно политичко упућује на идеолошки, позитиван моменат артикулације циља одређене културе, те на избор начина образовања како појединца, тако и заједнице, на велику причу о обликовању. ${ }^{13}$ Читава просвећеност, уосталом, чији највиши израз добијамо с Кантом, управо и јесте велика прича о самообразовању, о култури, а не о трансцендентном ауторитету, као покретачу самообразовања. У том погледу Ниче нипошто није супротност

Стојановића, стр. 106.

10 Кант, И. (1974) Идеја опште историје усмерене ка остварењу светског грађанскг поретка, ум и слобода, превод Баста, Д., Београд: Култура, став 8, стр. 36 .

11 Исто, ставови 4 и 5, стр. 32-33.

12 Исто, став 5, стр. 33.

13 Одличан преглед појма културе као процеса образовања даје Александар Добријевић у књизи Између образовања и самообразовања, Крајина плус, Бања Лука 2010. Такође: Димић, 3. (2013) Рађање идеје универзитета, Сремски Карловци/Нови Сад: Издавачка књижарница Зорана Стојановића. 


\section{ИВАН МИЛЕНКОВИЋ}

духу просветитељства, него један од најбољих његових изданака. Према знаменитом Ничеовом одређењу, култура је активност обликовања. Сврха културе био би активан и слободан човек, „суверена јединка која је само себи слична, која се моралности морала (Sittlichkeit der Sitte) поново ослободила, аутономна, надморална (übersittliche) јединка (јер 'аутономна' и 'морална' се узајамно искључују), укратко: човек независне и истрајне воље који сме да обећа..."14. Или, у Делезовом читању овог мотива, „производ културе није човек који се повинује закону, већ суверени појединац и законодавац који се дефинише преко моћи над самим собом, над судбином, над законом: слободан, лак, неодговоран"15. Како, међутим, разумети ова места, јер, чини се, један од неспорних циљева културе, барем онако како нам предаје дуга традиција која сеже од Платона и Аристотела, преко Лока и Канта до Џона Ролса, јесте стварање одговорног и моралног појединца, одговорне, моралне и праведне заједнице. Ниче, међутим, уводи нови појмовни поредак. Њега занима однос сила, игра акције и реакције, те оно што назива здравом културом, културом која се посматра са историјског становишта. Посматрати, пак, културу са историјског становишта, значи видети да у култури не постоје нужности, да не постоји ништа суштинско неке културе, већ да је она увек процес обликовања и, пре свега, самообликовања.

\section{Ресантиман и деполитизацчија културе}

Нормално или здраво стање одређене културе, односно политичке заједнице, карактерише отворен и пожељан однос акције и реакције: свака акција захтева реакцију и свака реакција ограничава акцију. Реакција успорава акцију, а акција убрзава реакцију. То је ноторни физички закон који важи и за организовану политичку заједницу. Уколико, рецимо, власт својом акцијом наноси штету заједници, реакција је ту да постави брани и, ако је могуће, штету ублажи или умањи. У уређењу демократског типа (демократске културе) опозиција је институционализована реакција. У аутократском поретку, пак, реакција је непожељан политички гест, а култура функционише само као елемент хомогенизације политичке заједнице, дакле култура пасивизује и деполитизује, обликује пасивну јединку која не само да не реагује, већ реагује једино када треба сузбити некакву или нечију

14 Ниче, Ф. (1993) Генеалогија морала, превод Ерњаковић, Г., Београд: Српска књижевна задруга, II, 2, стр. 270. Упоредити: Делез, Ж. (1999) Ниче и филозофија, превод Стојановић, С., Београд: Плато, стр. 162-163.

15 Делез, Ж. нав. дело, стр. 163. 
реакцију. Комунисти су, у том погледу, били јасни: реакцију ваља затрти, а култура служи изградњи новог, социјалистичког (нат)човека, човека непрестане и неупитне акције, човека који не реагује (осим на реакцију) јер нема на шта да реагује будући да је он једини и неприкосновени субјект акције. ${ }^{16}$ Совјетска култура, рецимо, имала је јасан задатак што га је артикулисала институционализована политичка воља (дакле не из духа саме културе, из онога што Вебер зове „вечно јуче” 17 већ из духа комунистичке клике): створити новог човека. Тај човек је, међутим, суштински деполитизован јер он има извршавати налог вође, централног комитета, или комесара. Совјетска култура није остављала могућности, она није образовала за избор, већ за послушност, за оно Боесијеово добровољно ропство. Без слободе нема ни политике. Једва да је потребно рећи да сваки тоталитарни, или ауторитарни систем, тежи успостављању новог човека обликованог једном културом и једним културалним начелом. Бити проглашен реакцинаром у социјалистичкој Југославији, на пример, значило је грађанску, а у почецима успостављања новог поретка и сасвим стварну смрт. Реакција се препознавала не само на политичком плану у виду супротстављања новоуспостављеној власти, већ и као носилац „реакционарне културе”. Култура је, у тоталитарном поретку, потчињена политички одређеним циљевима, с тим што циљеве артикулише појединац, вођа, Führer, duce, или клика окупљена око њега. ${ }^{18}$ У тоталитарном поретку политика стиче аутономију у односу на културу, што нарочито важи за комунистички тоталитаризам: тамо је политика наступала у име универзалних принципа, те се културално наслеђе, утолико, већ по дефиницији имало сматрати реакционарним,

16 Онај бењаминовски парадокс штрајка који је (штрајк), истовремено, и у радном процесу и изван њега, обуставом рада радници се боре за рад, у обрнутом смислу присутан је и у комуниситчкој варијанти власништва над средствима за производњу. Наиме, ако су радници власници тих средстава штрајк је, по дефиницији, бесмислен. У тоталитарној култури je, дакле, реакција бесмислена пошто постоји само акција, само делатност субјеката културе.

17 Вебер, М. нав. дело, стр. 104.

18 Мартин Малиа ће, у нешто ширем контексту, хотећи да направи разлику између комунистичког и нацистичког тоталитаризма, да проговори о „генеричком комунизму”, док се, по његовом мишљењу, теза о некаквом „генеричком фашизму” заправо не може одржати. Комунистички режими су, наиме, имали неколико заједничких црта, док су фашизми, у том погледу, били разуђенији. Овом разликовању Малиа приступа из перспективе појма зла, али нама се чини да се ово разликовање да одржати и кроз анализу улоге културе у ова два тоталитарна поретка. Упоредити: Малиа, М. Нацизам - комунизам: скица за поређење, у: Мање зло. Морални приступи праксама геноцида, ур. Хелмут, Д. и Моцкин, Г. (2005), Београд/Загреб: Београдски круг/Мултимедијални институт, стр. 15 и даље. 


\section{ИВАН МИЛЕНКОВИЋ}

одвећ неуниверзалним, посебним, националним, да би могло бити озбиљније размене између политике и културе. ${ }^{19}$ Нацизам се, томе насупрот, ослањао на чврсте културалне темеље, на оно „вечно јуче”: расна теорија је „достигнуће” културе. Утолико су оба модела имала логор као своју парадигму, као место за реакцију, као оно без чега не би могли да постоје јер, строго узев, у тим моделима на делу није била политичка култура, већ, у случају комунизма, политика одвојена од културе, а у случају фашизма/нацизма политика културализована до убилачких граница. У комунизму је политичком интервенцијом одрезана прошлост и читава се грађевина ослањала на обећање боље будућности, у нацизму се, пак, према политичком тумачењу, делало из духа митске прошлости. У оба случаја, међутим, култура мора бити деполитизована, односно банализована. С једне стране култура задржава своју основну функцију обликовања, али као потпуно зависна од воље вође она ту функцију не испуњава на терену слободе, нити је слобода њен циљ. Другим речима, без слободне сфере јавности, култура није политичка. Култура без реакције у себи своди се на пуку дресуру, на свој, што би рекао Ниче, праисторијски период, уроњеност у „моралност морала”. ${ }^{20}$ Разлика између поштеног совјетског грађанина који је прошао курс совјетске културе и добро истренираног тигра који, уз пуцкетање бича, скаче кроз пламени обруч, није лако уочљива. Циљ тоталитарне културе није слободан, самосвестан појединац, већ суверена заједница робова. Тамо, дакле, где изостаје реакција свака је акција легитимна већ тиме што је акција. Самим тим она је праведна и најбоља. У таквом поретку речи и ствари, међутим, нема ничег здравог. На делу је начело ресантимана.

Ресантиман је одсуство активирања реакције. И реакција је некаква акција, узвраћање. Узвратити, одреаговати, значи активирати реакцију. Али ако се реакција не активира, ако изостане било из ког разлога - страх, лењост, глупост, насиље (одмах ваља додати да су данас, у ономе што је остало од јавне сцене у Србији, на делу сва четири разлога) - главну реч преузима начело ресантимана: не реаговати. ${ }^{21}$ Реакција

19 Цветан Тодоров, додуше, сматра да је реч о бркању интернационалног и универзалног, те сматра да је комунистички партикуларизам једнак фашистичком. Тодоров, Ц. (2005) Употребе и злоупотребе поређења, у: Мање зло. Морални приступи праксама геноцида, ур. Хелмут, Д. и Моцкин, Г. (2005), Београд/Загреб: Београдски круг/Мултимедијални институт, стр. 47.

20 Упоредити: Делез, Ж. нав. дело, стр. 158 и даље.

21 Књига Философија паланке Радомира Константовића (Београд: Откровење 2004) показује да је нереаговање кључно својство, принцип духа паланке. Последица је нихилистички став према животу као могућно- 


\section{ИВАН МИЛЕНКОВИЋ}

која не активира сопствени одговор на акцију остаје непокретна, парализована, неделатна. Одсуство реакције корумпира и саму акцију која, будући да не наилази на отпор, постаје инертна, самосврховита, у својој разобручености пасивна, као свемирска летелица која је савладала отпор Земљине теже и атмосфере и сада, ношена сопственим замахом, плута свемиром. Без отпора акција постаје реактивна: она не производи, не ствара, она чека да буде покренута и, у свом чекању, постаје осетљива на оно што долази из сећања. Неактивном заједницом, као и неактивним човеком, почињу да овладавају трагови прошлости. Тај феномен познат је код старијих људи који се јасније сећају давне прошлости него онога шта су радили пре два сата. Реалност, због тога, постаје иста јер се не оправдава непрестаним преображајем, већ се окамењује да би вечито одговарала себи самој, да би била једнака себи. Реалност и прошлост улазе у нездрав симбиотички однос у којем се реалност оправдава прошлошћу, док се и сама прошлост стврдњава, постаје крути знак (стереотип) на који се ставља забрана тумачења: нема се шта тумачити пошто се све догодио управо онако како се догодило, неповратно.

Као лек против петрификовања живота, против навале сећања, Ниче нуди заборав.

\section{Култура заборава}

Заборав није пуко негативно одређење, сугерише Ниче, које се разуме као некакав мањак, недостатак, неприсуство, или одсуство памћења, већ је заборав позитивна сила која се супротставља пасивности на коју је позива чудесно памћење. „Без заборавности”, пише Ниче, „не би могло бити никакве среће, ни ведрине, ни наде, ни поноса, па ни садашњости"22. Оваква интервенција најдиректније се супротставља култури сећања, оној културалној делатности која је готово уписана у наш културални код. По том одређењу култура јесте сећање, чување и обликовање сећања, организовање сећања

сти и затварање у „реализам”. Није, дакле, нихилизам пуко порицање моралних вредности, већ порицање активности која вредности преображава, порицање могућности, „порицање времена“ (стр. 83), порицање активне културе у име фетишизирања реалности (стр. 82). Упоредити: Делез, нав. дело, стр. 175 и даље: Нихилизам није небиће, већ ништавна вредност, дакле вредност коју инаугурише дух паланке, банална вредност, неполитичка вредност. Проблеми савремене етике, нарочито онога што долази са енглеског говорног подручја, биоетика рецимо, своде се на то што остају у огради „моралности морала”, што настоје да етичке проблеме извуку из историје, да им одузму временитост, њихову политичку димензију.

22 Ниче, Ф. нав. дело, II, 1, стр. 268-269. 


\section{ИВАН МИЛЕНКОВИЋ}

као политичка делатност. ${ }^{23}$ Заједнице су увек заједнице сећања. Но, ако то није спорно, проблеми почињу оног тренутка када поставимо питање ко одређује шта ће се памтити, због чега и на који начин? Најзад, парафразирајући знамениту Лајбницову дилему, можемо питати „зашто пре памћење, а не заборав”? Ако је сећање политичка величина, зашто и заборављање не би могло бити политички пројекат, под условом, додуше, да идеја заборава не долази из већ познате перспективе која би да у заборав гурне оно непријатно у прошлости, као кад појединац жели да заборави лошу прошлост? Тамо где постоји мање или више јасна стратегија заборава, та стратегија почива на истим механизмима на којима почива и пројекат сећања, наиме на претходно датим идентитетима и на познатим идентификацијама. У „теорији заборава", међутим, кључни моменат је разидентификација. Заборав је, сугерише Ниче, активност. „Заборав никако није само обична vis inertiae, како то верују површни људи; она je, напротив, активна, у најстрожем смислу позитивна моћ кочења којој треба да захвалимо да нам оно што смо само ми доживели, искусили, усвојили, у фази варења (...) стиже до свести исто тако мало као читав хиљадоструки процес у коме се збива наше телесно исхрањивање, такозвано 'утеловљавање'”24. Као активност заборав је својеврсна „чуварка”, или „вратарка” која спречава мешање два реактивна апарата. ${ }^{25} \mathrm{C}$ једне стране, дакле, свест је увек реактивна, она прима спољашње надражаје, али у себи, као што је раније показано, садржи две приматељске димензије: једну која реагује одмах, која, дакле, постаје реакција не присутни надражај или непосредну слику предмета (свест у ужем смислу), онај део свести који не реагује на трагове - јер трагови долазе из подсвести, из оног несвесног, они се пењу до свести -

23 Изврсну критику културе као петрификаторке, чуварке сећања, можемо пронаћи у књизи: Асман, А. (2013) Дуга сенка прошлости, превод Гојковић, Д., Београд: XX век, као и изврсном у тексту: Павићевић, Ђ. Политичко памћење: нормалан случај у патологији, у: Ђерић, Г. (2009) Памћење и носталгија, Београд: Институт за филозофију и друштвену теорију и Филип Вишњић, стр. 115-137.

24 Ниче, Ф. нав. дело, II, 1, стр. 268. Упоредити: Ниче, Ф. (2006) О користи и штети историје за живот, у: Несавремена разматрања, превод Баста, Д., Београд: Плато, стр. 77-78: „И код најмање и код највеће среће свагда постоји нешто услед чега срећа постаје срећа: моћ заборављања, или, ученије изражено, моћ да се током њеног трајања осећамо неисторијски. Ко не може да застане на прагу тренутка, заборављајући сву прошлост, ко није кадар да као богиња победе без вртоглавице и страха стоји на једној тачки, тај никада неће знати шта је срећа, још горе: он никада неће учинити нешто што ће друге усрећити. (...) сасвим је немогуће да се уопште живи без заборава" (стр. 78).

25 Ниче, Ф. нав. дело, II, 1, стр. 268; Упоредити: Делез, Ж, нав, дело, стр. 135. 


\section{ИВАН МИЛЕНКОВИЋ}

већ „обнавља покорицу увек свеже пријемчивости” правећи места за ново 26 ; с друге стране, пак, имамо реакцију на мнемоничке трагове, на надражаје који долазе из несвесног, дакле из прошлости. Иако у основи реактивна, свест може да покрене реакцију и тада постаје нешто активно, односно, прецизније, (само)активирано. До „закрчења”, међутим, долази када мнемонички трагови навру у свест с таквом силином и у таквој количини да она, напросто, престане да функционише нормално. Будући преплављена мнемонички траговима, она више није у стању да прима надражаје споља, садашње надражаје, него је потпуно окренута ономе што долази изнутра, из ње саме, из ускладиштене прошлости. Услед закрчења путева, рецептивни апарат почиње да бива нефункционалан, долази до функционалног поремећаја: очи, иако гледају, не виде, уши, иако слушају, не чују, здрав разум више не значи ништа, а дотад препознатљиви и блиски облици (Хрват, Србин) постају чудовишта бића таме, зло (усташа, четник), уза све пратеће феномене самоидентификација. Свест се усредсређује на оно што је било и то прошло доживљава као оно што јесте, док се садашњост, или оно што јесте, претвара у далек и неразговетан шум, у непријатељску могућност која ремети самодовољност контемплације прошлог. Тада је немогуће дати обећање, једну од највиших људских активности, јер живот човека прошлости је „имперфекат што се никада не завршава”27. Онај код кога је апарат за заборављање оштећен, код кога престане да ради, „може се упоредити (и не само упоредити) с човеком с лошим варењем: на крају ништа више не може да се свари" 28 , односно ни са чим не може да изађе „накрај”.

Образовати активног, дакле самосвесног, сувереног појединца, грађанина, значи научити га да се одупре колективном сећању. То је појединац који савлађује страх од могућих последица - изопштење из заједнице, политичка репресија - да би афирмисао вредност заборава. Не сећати се онога чега се сви сећању, цара Константина, косовске битке, Гаврила Принципа, јуначког ратног похода на цивиле - непристајање на склоп (agencement) ${ }^{29}$ који нас увек већ унапред одрећује, па дакле ни на сећање, већ на делотворни заборав. Како, међутим, уградити „теорију заборава” у културу која се одређује сећањем? Одговор даје управо Аристотел својом дефиницијом грађанина који се, истовремено, учи владању

\section{6 Исто.}

27 Ниче, Ф. нав. дело, стр.78.

28 Ниче, Ф. нав. дело, II, 1, стр. 269 (превод измењен).

29 Упоредити: Делез, Ж. и Парне, К. (2010) Дијалози, превод Петронић, О., Београд: Федон, стр. 30, 89-96. 


\section{ИВАН МИЛЕНКОВИЋ}

и учи се томе да се њиме влада. ${ }^{30}$ Тек тада он може бити она суверена Ничеова јединка „која је само себи слична”, „аутономна и надморална", што, никако не значи аморална. Аморална јединка не уочава односе у заједници. Аристотелов грађанин, међутим, зна да постоје извесна правила, правила која учи, али он учи и да је законодавац, да је, као политичко биће, онај ко доноси одлуке. Законодавац зна да је закон увек пред његовим погледом, да његов закон захтева реакцију, да је та реакција потребна његовом закону. Ничеова реч „неодговоран”, утолико, не значи онај ко закон не поштује, већ онај ко је у стању да закон донесе. Он зна да мора да заборави оно на чему почива морал, вредност из које морал црпе снагу, дакле моралност самога морала, да би раскрчио простор за ново. Он зна да култура мора бити гипка да би, уопште, била делотворна. Томе насупрот, склеротизована култура своју делотворност показује у самодеструкцији. Зато је потребно заборављати. У пројекту заборављања нема јемстава, али неизвесност и јесте одлика републиканског образовања, тог образовања за мноштвеност у којем, уместо јемстава и олаких обећања, постоје само обезбеђени путеви.

\section{ЛИТЕРАТУРА:}

Arendt, H. (1958) Conditio humana, Chicago/London: The Universsity of Chicago Press.

Аристотел (1975) Политика, Београд: БИГЗ, превод Љиљана Станојевић-Црепајац.

Асман, А. (2011) Дуга сенка прошлости, Београд: XX век, превод Дринка Гојковић.

Делез, Ж. (1999) Ниче и филозофија, Београд: Плато, превод Светлана Стојановић.

Делез, Ж. (2009) Разлика и понављање, Београд: Федон, превод Иван Миленковић.

Делез, Ж. и Клер, П. (2009) Дијалози, Београд: Федон, превод Оља Петронић.

Димић, 3. (2013) Рађање идеје универзитета, Сремски Карловци/ Нови Сад: Издавачка књижарница Зорана Стојановића.

Добријевић, А. (2010) Између образовања и самообразовања, Бања Лука: Крајина плус.

Кант, И. Идеја опште историје усмерене ка остварењу светског грађанског поретка, у: Ум и слобода (1974) Београд: Култура, превод Данило Баста.

30 Аристотел (1975) Политика, превод Станојевић-Црепајац, Љ., Београд: БИГЗ, 1277 а, 7, стр. 59. 


\section{ИВАН МИЛЕНКОВИЋ}

Константиновић, Р. (2004) Философија паланке, Београд: Откровење.

Kroeber, A. L. and Kluckhohn, C. (1952) Culture: a critical review of concepts and definitions, Papers, 47 (1) Cambridge, Mass: Peabody Museum of Archaeology and Ethnology.

Loraux, N. (1993) L'Invention d'Athènes: Histoire de l'oraison funébre dans la cité classique, Paris: Payot.

Малиа, М. Нацизам - комунизам: скица за поређење, у: Maње зло. Морални приступи праксама геноцида, ур. Хелмут, Д. и Моцкин, Г. (2005), Београд/Загреб: Београдски круг/Мултимедијални институт.

Миленковић, И. Политизација културе и култура политизације, у: Култура, род, грађански статус, ур. Духачек, Д. и Лончаревић, К. (2012), Београд: Центар за студије рода и политике, Универзитет у Београду, Факултет политичких наука.

Milenković, I. (2014) Nemoguće identifikacije Jacquesa Rancièra, Up \& Underground br. 25/26, Zagreb.

Миленковић, И. (2015) Парадокси контекста: хетеротопије Мишела Фукоа, Култура бр. 147, Београд.

Ниче, Ф. (1993) Генеалогија морала, Београд: Српска књижевна задруга, превод Глигорије Ерњаковић.

Ниче, Ф. (2006) О користи и штети историје за живот, у: Несавремена разматрања, превод Данило Баста, Београд: Плато.

Павићевић, Ђ. Политичко памћење: нормалан случај у патологије, у: Памћење и носталгија, ур. Ђерић, Г. (2009), Београд: Институт за филозофију и друштвену теорију и Филип Вишњић.

Рансијер, Ж. (2012) На рубовима политичког, превод Иван Миленковић, Београд: Федон.

Рансијер, Ж. (2014) Несагласност, превод Иван Миленковић, Београд: Федон.

Шмит, К. (2001) Појам политичког, Норма и одлука, превод Данило Баста, Београд: Филип Вищњић.

Тодоров, Ц. Употребе и злоупотребе поређења, у: Maње зло. Морални приступи праксама геноцицда, ур. Хелмут, Д. и Моцкин, Г. (2005), Београд/Загреб: Београдски круг/Мултимедијални институт.

Вебер, М. (1998) Политика као позив, Духовни рад као позив, Сремски Карловци/Нови Сад: Издавачка књижарница Зорана Стојановића, превод Душан Јанић. 


\title{
ИВАН МИЛЕНКОВИЋ
}

\section{Ivan Milenković}

University in Belgrade, Faculty of Political Sciences; Radio Begrade, Third Programme, Belgrade

\section{POLITICAL CULTURE AS A CULTURE OF OBLIVION}

\begin{abstract}
If dealing with our past is a significant segment of every culture then politics could be defined as directing our memory. Starting with Nietzsche's notion of ressentiment and Deleuze's reading of Nietzsche, this article aims to show the ways and conditions under which politics articulates the goals of a culture. A healthy, active, productive culture shapes a sovereign and self-conscious citizen, a free individual who can react. The culture of ressentiment, on the contrary, creates a community of vassals who, according to the Nietzsche-Deleuzian formula, do not activate their reaction, all in the name of a petrified past. To the petrified and instrumentalized memory Nietzsche opposes the power of forgetting as a certain cure.
\end{abstract}

Key words: Nietzsche, Deleuze, memory, oblivion, culture, politic culture, paradox

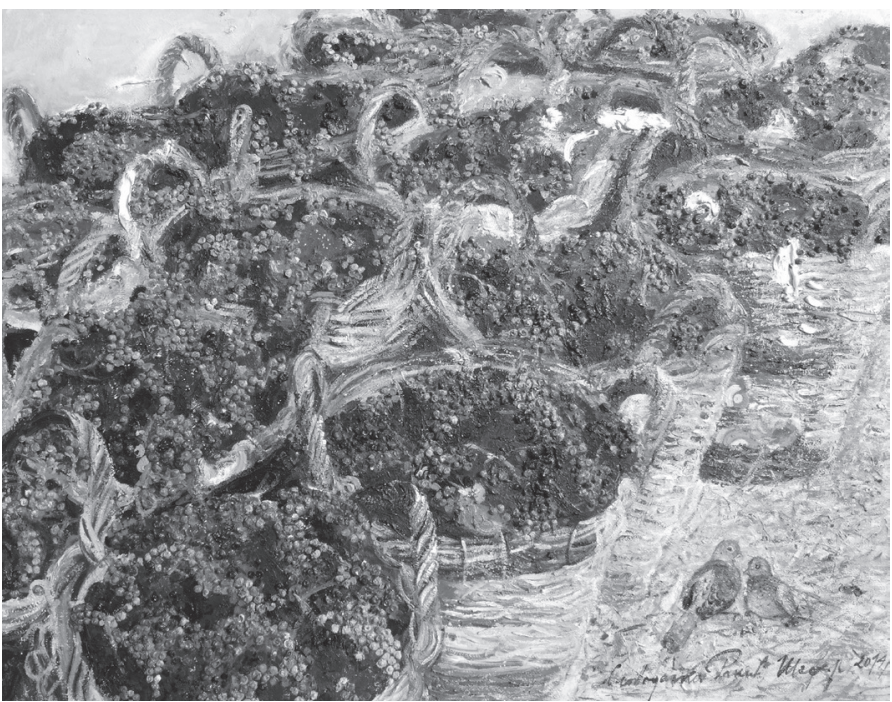

Слободанка Ракић Шефер,

Берићетна берба, уље на платну, 2014-2015. 